\title{
A ESTREITA RELAÇÃO ENTRE A COMUNICAÇÃO EFETIVA E A GESTÃO DEMOCRÁTICO-PARTICIPATIVA
}

\author{
CLOSE RELATIONSHIP BETWEEN THE EFFECTIVE COMMUNICATION \\ AND DEMOCRACY - PARTICIPATORY MANAGEMENT
}

\author{
Vanessa Rita BARAZZETTI ${ }^{1}$ \\ Willie Anne M. da Silva PROVIN ${ }^{2}$ \\ Sirley Terezinha FILIPAK ${ }^{3}$
}

RESUMO: O presente artigo analisa os conceitos de comunicação efetiva e de gestão democrático-participativa e a relação entre estes dois termos. Aspectos como os benefícios que o trabalho em conjunto desses dois termos oferece para a atuação dos gestores/gestoras e os problemas que podem ocorrer caso não haja a interação entre esses dois principais conceitos, são explanados neste texto. Baseado, principalmente, nas pesquisas de $\operatorname{DEMO}(2009)$, FRANÇA(2013) e HABERMAS(1987), este artigo parte do pressuposto de que parte dos gestores/gestoras de instituições de ensino possui o conhecimento, mas não consegue executá-lo de maneira efetiva. É neste ponto que com relação ao foco educacional, torna-se fundamental a estreita relação entre a comunicação efetiva e a gestão democrático-participativa para o sucesso da comunicação pretendida.

PALAVRAS-CHAVE: Comunicação Efetiva. Gestão Democrático-Participativa. Educação. Interação.

ABSTRACT: This article analyzes the effective communication and democratic participative management concepts and the relationship between these two terms. Aspects such as the benefits that working together these two terms provides for the performance of managers and the problems that can occur if there is no interaction between the two key concepts are explained in this text. Based mainly in DEMO (2009), FRANCE (2013) and Habermas (1987) research, this article assumes that the managers of educational institutions have the knowledge, but can not run it so effective. It is at this point that in relation to the educational focus, it is essential the close relationship between effective communication and democratic participative management to the success of the intended communication.

KEYWORDS: Effective Communication. Democratic-Participative Management. Education. Interaction.

\section{Introdução}

${ }^{1}$ Mestranda em Educação da Pontifícia Universidade Católica do Paraná. E-mail: assessoriajornalistica@hotmail.com.

${ }^{2}$ Mestranda em Educação da Pontifícia Universidade Católica do Paraná. E-mail: willieprovin@gmail.com.

${ }^{3}$ Doutora em Educação e Professora da Pontifícia Universidade Católica do Paraná. E-mail: sirley.filipak@pucpr.br. 
Apresentar e discutir a importância da aplicação da comunicação efetiva dentro da Educação Superior, por meio de uma gestão democrático-participativa, baseada em uma visão sociocrítica, é o principal objetivo deste artigo. A comunicação e a participação são conceitos diretamente ligados, um não funciona sem o outro. Diversos ruídos existentes entre emissores e receptores acontecem pelo simples motivo de não ocorrer o trabalho da comunicação e da participação em conjunto.

Quais os conceitos e qual a importância da comunicação e da comunicação efetiva, da gestão e da gestão democrático-participativa, além da relação clara e direta que as duas áreas possuem uma com a outra, são temas abordados neste artigo.

O grande aspecto que torna este assunto de extrema importância é o entendimento do espaço, da cultura, dos costumes, do papel, do perfil e da função do outro na sociedade atual. Tendo esses aspectos como norteadores do seu trabalho, o gestor/gestora educacional deve ter a iniciativa e o interesse em ouvir os seus colaboradores e em analisar o ambiente e o público com os quais está inserido e é partícipe, dessa forma a gestão participativa torna-se natural e a comunicação torna-se efetiva.

Autores como: Freire (1993); Cittadino (1999); Demo (2009); França (2013); Cadermatori (2013); Libâneo (2007), tratam de conceitos relacionados à importância da comunicação, do papel do emissor, receptor, da mensagem, da função da gestão e do gestor, conceitos estes utilizados no presente artigo.

A metodologia utilizada é bibliográfica, citando, principalmente, o pensamento de Corrado (1994), que é voltado à crítica ao mercado e instituições que utilizam de profissionais não especializados em comunicação para elaborar formações ou qualquer outro aspecto nesta área, e do pensamento de Bernardi (1995), que trata da questão do sucesso da gestão participativa, sendo diretamente vinculada à aplicabilidade da comunicação efetiva.

Com isso, o gestor/gestora educacional passa a ter mais estratégias para o bom andamento de seu trabalho, os professores e demais colaboradores adquirem vontade e iniciativa de opinar e auxiliar a gestão da instituição, tendo o sentimento de reconhecimento, e finalmente, os alunos e comunidade passam a contar com um trabalho educacional de sucesso, afetando diretamente o ensino deste público.

\section{Comunicação e sua importância}


A comunicação pode ser considerada toda e qualquer informação, seja ela escrita, falada ou em forma de figuras, que é repassada de um emissor para um receptor, mas a comunicação efetiva não é simplesmente repassada, ela deve cumprir o objetivo inicial. O receptor deve entender realmente o que o emissor quis informar, não interpretar de forma diferenciada, dessa maneira, acontece uma comunicação considerada então efetiva.

Uma mensagem ou informação não é comunicação senão de modo relativo. Primeiramente, ela é comunicação em relação àqueles que podem torná-la enquanto tal, isto é, não como coisa, mas como da ordem do simbólico. Como exemplo, tome-se a página de um livro. Para um animal, ou para uma pessoa analfabeta ou que não conheça o idioma utilizado (código), a página não é senão uma coisa, um objeto, não chegando absolutamente a se constituir enquanto mensagem. (HOHLFELDT; MARTINO; FRANÇA, 2013, p.16).

O entender a informação não é suficiente para que aconteça a aplicabilidade do conteúdo repassado. Muitas pessoas possuem o conhecimento e não conseguem executá-lo de maneira correta e efetiva, não tendo o cuidado de diferenciar o público com o qual está trabalhando.

A resposta mais imediata à questão, trazida pela nossa vivência (ou senso comum), vai resgatar - ou apoiar-se - na sua dimensão empírica: trata-se de um objeto que está à nossa frente, disponível aos nossos sentidos, materializado em objetos e práticas que podemos ver, ouvir, tocar. A Comunicação tem uma existência sensível; é do domínio do real, trata-se de um fato concreto de nosso cotidiano, dotada de uma presença quase exaustiva na sociedade contemporânea. Ela está aí, nas bancas de revista, na televisão da nossa casa, no rádio dos carros, nos outdoors da cidade, nas campanhas dos candidatos políticos e assim por diante. Se estendermos mais os exemplos (e também nosso critério de pertinência), vamos incluir nossas conversas cotidianas, as trocas simbólicas de toda ordem (da produção dos corpos às marcas de linguagem) que povoam nosso dia a dia. (HOHLFELDT; MARTINO; FRANÇA, 2013, p.16).

O termo "comunicação efetiva", de França (2013), embora voltado especificamente para o estudo do jornalismo, faz parte de uma teoria cuja aplicabilidade é mais ampla e ajuda a derrubar o mito da imparcialidade profissional, segundo o qual a produção sofreria apenas condicionamentos de ordem externa (dos fatos, da sociedade, do patrão, da ideologia), apontando aspectos internos, ligados à natureza do trabalho, ao 
âmbito das relações profissionais, bem como às representações e imagens que cercam a profissão. Estas diferentes abordagens destacam a centralidade e papel determinante dos emissores no processo comunicativo, quando não um papel dominador frente a um receptor indefeso.

Para a comunicação atingir o nível de efetividade, ela passa por dois outros níveis anteriormente: pela eficácia que consiste em identificar como e que ferramentas serão utilizadas para obter uma comunicação efetiva, passa também pela eficiência que é a atitude que será tomada a partir da identificação do que pode ser realizado para chegar até a comunicação efetiva. A junção destes dois conceitos forma a comunicação efetiva, que é o resultado obtido, ou seja, é o entendimento e a aplicação do receptor daquilo que foi falado pelo emissor.

A comunicação quando bem aplicada exerce uma influência extremamente poderosa sobre o público que deseja atingir. E esse fator pode ser visto positivamente ou negativamente. Uma informação sendo divulgada por meio da mídia, que beneficie como um todo um segmento ou grande parte da população é algo positivo ou também uma informação pode ser manipulada por interesses individuais, nesse caso ela passa a ser vista como negativa.

A existência do poder midiático não é negativa de per se, pois é natural, e até mesmo desejável, que existam poderes paralelos ao Estado. Esses poderes não devem, contudo, permanecer invisíveis ao controle do poder exercido legitimamente no Estado democrático de direito, pois tal situação viola uma das maiores promessas da democracia: a visibilidade e controle do poder - inclusive os não estatais. (CADEMARTORI; MENEZES NETO, 2013, p.189).

A comunicação é entendida, muitas vezes, como algo interdisciplinar, como uma ferramenta que auxilia a execução de determinadas ações ou disciplinas, o que acaba sendo um equívoco. A comunicação possui a sua independência e autonomia, a partir do momento que é denominada dessa forma, os seus efeitos e principais objetivos têm maior êxito.

Podem ser citados exemplos de empresas que quando passam por crises financeiras, o primeiro setor que é cortado, é o de comunicação, pois parece que, para esses empresários, este é um setor supérfluo ou até mesmo de luxo, ter a existência de um departamento de comunicação, quando o local está passando por uma crise. 
A questão reside então na possibilidade de estabelecer a particularidade de um campo de análise de um saber que ora aparece como o fundamento das ciências do homem, ora aparece como uma síntese do produto dessas ciências. Em todo caso, o que se vê hoje em dia é a Comunicação passar diretamente do sentido filosófico para o sentido radicalmente interdisciplinar, sem espaço para a constituição de uma disciplina autônoma. (HOHLFELDT; MARTINO; FRANÇA, 2013, p.16).

Além de a comunicação ser extremamente importante em qualquer processo interdisciplinar, ela fundamenta e cria novos conceitos também em processos isolados, ou seja, na gestão democrático-participativa propriamente dita e nas relações que ela estabelece com os públicos diferenciados que atinge com as práticas variadas que exerce.

A efetividade da comunicação depende de diversos componentes: do contexto pelo qual a pessoa, a mensagem e/ou a situação está inserida, a linguagem corporal que o indivíduo utiliza, as interferências existentes e depende também da escuta ativa do receptor. Em seguida serão explanados um pouco dos conceitos destes componentes que formam a comunicação efetiva.

O contexto leva em consideração a idade, região, sexo e habilidades intelectuais de quem recebe a informação. No momento da comunicação, também é útil avaliar a receptividade e o estado emocional de quem envia e recebe a informação. Pode-se afirmar que, dentre as interferências pelas quais a comunicação efetiva pode ser afetada, citam-se como exemplo as emoções. Se a pessoa que envia a informação estiver nervosa, sua habilidade de enviar mensagens eficazes pode ser afetada negativamente. Da mesma maneira, se a pessoa que recebe a informação estiver chateada ou discordar da mensagem ou de quem a envia, ele pode ouvir algo diferente que era pretendido ser passado. Considerar as emoções, linguagem e barreiras conceituais é essencial para uma comunicação efetiva.

A comunicação não-verbal, outro componente da comunicação efetiva, consiste na linguagem corporal que inclui postura, posição das mãos e braços, contato visual e expressão facial. A linguagem corporal combinada ao conteúdo verbal melhora o entendimento. A comunicação efetiva requer que o conteúdo e a linguagem corporal passem a mesma mensagem.

A comunicação efetiva é um processo recíproco que inclui escuta. Para escutar com sucesso, é necessário contato visual, processamento do objetivo e resposta para quem envia a mensagem. A escuta ativa pode envolver perguntas para melhor 
entendimento ou repetição do que foi ouvido para assegurar que a intenção da mensagem enviada foi recebida corretamente.

Outros fatores que determinam a efetividade da comunicação aplicada podem ser definidos, como por exemplo, os valores, costumes e bagagem cultural que o receptor da mensagem possui, a forma como esta pessoa (o receptor) age e reage diante de situações diferenciadas.

Os atores estão sempre se movendo dentro do horizonte do seu mundo da vida, eles não podem se colocar de fora dele. Como intérpretes, eles próprios pertencem ao mundo da vida, por meio de seus atos de fala, mas não podem se referir a "algo no mundo da vida" da mesma forma que podem fazer com fatos, normas e experiências subjetivas (HABERMAS, 1987a, p. 125-126).

A ideia de que a sociedade é hegemônica, que pensa, faz e toma atitudes iguais, não existe. Todas as pessoas vivenciam diariamente momentos variados, adquirem conhecimentos que são armazenados de formas e em tempos totalmente diferentes, e estes fatores influenciam diretamente e indiretamente se a comunicação aplicada será realmente efetiva.

\section{Gestão e gestão educacional}

Hoje em dia, o papel do gestor/gestora é abordado constantemente nas organizações empresariais e nas instituições de ensino superior públicas ou privadas. $\mathrm{O}$ gestor/gestora, ao lidar com pessoas e situações diferentes em seu cotidiano, deve priorizar a prática de saber ouvir seus colaboradores, fazendo com que estes sintam-se motivados a opinar e a entender as considerações que se apresentam. Esses são alguns dos desafios que os gestores atuais passam diariamente em seus mais variados locais de trabalho, como esse profissional irá administrar o andamento adequado dos processos e alcançar os objetivos desejados.

Diante disso é preciso que o gestor/gestora de uma instituição de ensino seja ela da educação básica ou superior, pública ou privada, tenha claro quais são os princípios que regem uma administração escolar e que a diferencia da administração empresarial. Com essa preocupação, já em 1961, foi criada no Brasil a ANPAE (Associação Nacional de Política e Administração da Educação), durante o I Simpósio Brasileiro de 
Administração Escolar e Educação Comparada, realizado em São Paulo, com a presença de José Querino Ribeiro, Anísio Spínola Teixeira, Lourenço Filho, Moysés Brejon, Carlos Corrêa Mascaro, entre outros professores de Administração Escolar da Universidade de São Paulo (USP). Surgiu como uma entidade que congregava professores preocupados com a delimitação e a natureza desse campo de conhecimento e seu ensino no país, desde então realiza simpósios e seminários dedicados à discussão do tema (MACHADO, 2002). Criada no mesmo ano da publicação da primeira LDBEN (Lei de Diretrizes e Bases da Educação Nacional), no governo de João Goulart, quase trinta anos após ser prevista na Constituição de 1934, demorou em torno de treze anos para ser finalmente publicada. Seu surgimento aconteceu em um momento de efervescência social e cultural brasileiro que teve entre seus maiores colaboradores o professor Anísio Teixeira. Em suas reflexões acerca da criação da ANPAE, Anísio expressa:

Jamais, pois, a administração escolar poderá ser equiparada ao administrador de empresa, à figura hoje famosa do manager (gerente) [...] Embora alguma coisa possa ser aprendida pelo administrador escolar de toda a complexa ciência do administrador de empresa de bens materiais e de consumo, o espírito de uma e outra administração são de certo modo até opostos. (COLOMBO, p.08)

De acordo com os professores idealizadores da entidade, em Educação, o alvo principal é o educando, a que tudo o mais está subordinado cujo processo é absolutamente humano, já na empresa, o alvo principal é o produto material a que tudo o mais está subordinado. Sendo assim, justificou-se a criação da ANPAE como reguladora dos processos de administração escolar e como parte estruturante da garantia da educação para todos, legitimada inclusive pela LDBEN, e lançada como semente de um movimento nacional que contribuiu decisivamente para a consolidação da administração educacional como campo profissional de estudo no Brasil.

Após a criação de entidades como a ANPAE e da criação da LDBEN em 1961, renovada em 1971, foi necessária a sua atualização, na década de 1990 (lei n. ${ }^{\circ}$ 9.394/1996), baseada nos princípios da Constituição Federal de 1988, como mais uma tentativa de garantir o acesso universal à Educação, defendida pelos setores organizados da sociedade civil que apresentavam uma grande preocupação com os mecanismos de controle social do sistema de ensino. O controle social permite que os próprios cidadãos participem de alguma forma da gestão pública, propicia a vivência da própria 
democracia, pois, ao praticar esse controle, os cidadãos podem interferir no planejamento, na realização e na avaliação das atividades do governo. É essa participação que deve ser defendida por todos, para a legitimação e garantia do estado de direito.

Para Pedro Demo (2009, p.29) “em tese, o Estado seria a organização da sociedade civil em função dos interesses da sociedade civil [...] Na prática, porém, a constatação é outra: o Estado tende a tornar-se muito mais representante da parte dominante da sociedade, do que da parte dominada."

Tendo isso em vista e levando em conta que a própria educação se tornou também uma "mercadoria", é comum o pensamento de que os novos métodos de gestão desenvolvidos no mercado devem ser assimilados pela gestão da escola pública, tendendo a educação a uma lenta e temerosa entrega aos parâmetros do mercado. É uma tendência que se afirma: a dificuldade em se pensar o Estado com expressão de uma comunidade ético-política, como um campo de direitos desta comunidade, de cidadania e de oportunidades de convivência, como seu espaço de afirmação. Diante dessa ideia, acredita-se que deva-se ir além daquilo que é imediatamente administrativo, que antes de almejarmos ter entre nós bons profissionais tenhamos bons cidadãos, protagonistas de um reforma educacional para salvar a escola, dirigi-la e não apenas administrá-la. (MACHADO; FERREIRA, p.32, 2002).

É necessário entender ainda, que existe o caráter contextualizado dessas práticas organizacionais que impedem o seguimento de um padrão único, que possibilita a construção de uma prática única, voltada para a sua realidade, concretizando os direitos dos seus atores à participação nas instituições de ensino.

No modelo atual de sociedade organizacional, atrelado aos interesses do capital e aos conceitos da empresa privada, o papel ideal para um gestor/ gestora, seja de qualquer área, seria averiguar se as atividades que ocorrem dentro da programação, se os resultados prévios estão dentro do esperado para o projeto, como prazos e custos, principalmente. Deseja-se que se exerça o controle pertinente a um gestor/gestora, junto com sua equipe, para poder identificar se as etapas do projeto estão sendo realizadas conforme planejado, porém, conforme as deficiências já citadas, propício ao clima competitivo, ao projeto neoliberal de funcionamento empresarial, o projeto de gestão democrático-participativa não se desenvolve plenamente. Essa impossibilidade gera conflitos dos mais variados tipos e é com essa realidade que o gestor/ gestora se depara, sem visualizar a saída concreta, na maioria das vezes. 
Assim também acontece com a gestão no campo educacional, não realizada por profissionais de administração, sem a intenção aqui em tratar a educação como uma empresa, mas ao mesmo tempo, não podendo fugir dos princípios básicos de um gestor/gestora. Infelizmente, no Brasil, ainda predomina o modelo de gestão denominado de técnico-científico, no qual a versão mais recente é conhecida como modelo de gestão da qualidade total, baseada na hierarquia dos cargos e funções, nos procedimentos administrativos e na racionalização e eficiência dos trabalhos escolares. Neste caso, os gestores, em sua maioria professores, não possuem experiência em trabalhos burocráticos, e por esse motivo acabam direcionando toda sua atenção para essa área, de certa forma, nova no seu cotidiano. Sabe-se também que, considerando os trâmites legais que em nome da preocupação com a qualidade de ensino ceifam algumas iniciativas, na realidade, pouco de autonomia resta às instituições de ensino para elaboração de instrumentos como projetos pedagógicos e regimentos sendo que muitos já têm sua maior parte definida pela legislação. O próprio sistema de avaliação é um dos indicadores que, ao invés de servir de base para programações que contemplem a superação das dificuldades apontadas, os resultados são expostos e alocados em uma espécie de "ranking", o que passa a ideia de que a escola é a única responsável pelos resultados, ignorando-se as diferenças e as condições de funcionamento.

Como resultado, as instituições educacionais tornam-se burocráticas, paralisando a criatividade, o julgamento profissional e a inovação. As estruturas organizacionais e administrativas muitas vezes distorcem o processo educacional, ao invés de facilitá-la e de incentivá-la. A rigidez da burocracia educacional inibe a participação dos membros da comunidade na definição dos destinos da instituição e gestão. O que deveria haver é a cessão desse espaço burocratizado por formas mais ativas e autogestionárias para governar os sistemas educacionais diante de uma crescente aceitação de que o governo da instituição deve ser descentralizado, repensando o papel do dirigente.

A burocracia impede que o trabalho de gestão participativa se concretize uma vez que, dentro desse funcionamento, somente com uma equipe ampla, capacitada ao trabalho burocrático e com o objetivo de transformá-lo, com uma gestão pautada na delegação de tarefas e não centralizadora e com a aplicação de uma comunicação efetiva possa então ter sucesso. Fora isso, a experiência educacional do gestor/gestora não se concretizará caso permaneça o valor dado à prática burocrática no cotidiano educacional. 
É necessário esclarecer que, no Brasil, a expressão "organização e gestão da escola" não tem emprego unânime entre os estudiosos brasileiros do assunto, embora ocorra o mesmo com outras denominações. Na tradição dos estudos sobre a escola, já nas primeiras décadas do século $\mathrm{XX}$, as questões relacionadas com o planejamento, organização, gestão e controle de atividades educacionais estiveram vinculadas ao termo “Administração Escolar.”( LIBÂNEO, 2007, p.03).

É importante estar atento às distorções desses ideais de uma gestão democrática, pois surgem também tendências que se passam por democratizantes, mas que mantêm em seu interior, os ideais do mercado como, por exemplo, as integrantes do termo "nova gestão" (MACHADO; FERREIRA, 2002), que afloram sob fórmulas como "gestão de recursos humanos", "cultura organizacional", "empowerment", "responsabilização", "aprendizagem organizacional" e até "gestão centrada na escola", estas formas de denominar a mesma gestão caracteriza-se por transferir o controle da gestão para os próprios trabalhadores, que, como num círculo vicioso, colaboram para desenvolver os meios do seu próprio controle. É o poder disciplinar que se exerce através dessas ações normatizadoras do eu e dos outros.

O gestor/gestora educacional enfrenta desafios maiores que outro de uma organização de caráter empresarial, pois deve saber gerir situações que envolvem alunos, seus responsáveis e, principalmente, os seus colaboradores. Públicos totalmente diferentes, com anseios individualizados e com visões e objetivos próprios. Problemas de como atender esses anseios de segmentos extremamente diferenciados, sem perder o controle da situação, passam a ser norteadores do seu trabalho.

Com o objetivo de compreender as relações que se estabelecem no interior dessas instituições de ensino, apontam-se os problemas que geram conflitos no relacionamento interpessoal e as possibilidades, partir destes conflitos, da construção de algumas habilidades e no desenvolvimento de determinadas competências para trazer ao conhecimento aspectos positivos e negativos dos problemas enfrentados nas escolas (MACHADO; FERREIRA, 2002).

A participação e a colaboração dos funcionários também é fundamental para que aconteça o sucesso do trabalho de um gestor/gestora educacional. Para que essa colaboração seja alcançada, vai depender de como esse gestor/gestora lida diariamente com esse público e de como essa troca é realizada no âmbito profissional. É importante que saiba identificar que, mesmo com as dificuldades em organizar as questões administrativas e financeiras, deve estar atento ou atenta também às relações humanas que caracterizam determinado local de trabalho. Conhecer o corpo de funcionários, 
docente e discente, além de sua comunidade escolar, possibilita ao gestor/gestora intervir com maior propriedade nas diversas situações que porventura possam ocorrer.

Aqui surge a questão da formação desses gestores por meio de uma comunicação efetiva que oferece ferramentas que auxiliam no seu trabalho com colaboradores, comunidade, pais/responsáveis e alunos. E é importante destacar que essas ferramentas não substituem o relacionamento direto que o gestor/gestora deve ter com seus próximos, elas apenas ajudam na manutenção daquilo que já foi estabelecido perante um estudo e prévia análise. Destacando que a formação desses gestores por meio de uma comunicação efetiva deve ser realizada por profissionais da área. Porque o que é feito erroneamente, é colocar um administrador ou consultor de qualquer outro segmento menos o de comunicação, por exemplo, para formar esses gestores.

\footnotetext{
Para preencher esse vazio na administração das comunicações, marcharam todos os tipos de especialistas - advogados, administradores de recursos humanos e mercadológicos - a fim de gerenciar as comunicações em substituição ao relações públicas tradicional. (CORRADO, 1994, p.15).
}

Um novo modelo de gestão poderá reverter as relações de poder entre as pessoas, a construção e uso das estruturas físicas e a utilização dos recursos tecnológicos, materiais e econômico-financeiros poderá contribuir para o surgimento de uma organização com potencial para realizar a gestão do conhecimento em um ambiente de aprendizagem contínuo e uma revisão dos processos pedagógicos e administrativos, fortalecendo a gestão com a tomada de decisões coletiva, com estratégica e competência. De acordo com Rocha (2003), o conceito geral e competência aqui adotado, consiste em saber atuar com responsabilidade integrando recursos, inclusive conhecimento, no sentido de aprender a aprender, com o propósito de agregar valores aos indivíduos e a organização.

\section{A gestão democrático-participativa legitimida pela comunicação efetiva}

A formação dos gestores educacionais por meio de uma comunicação efetiva pode ser resumida da seguinte forma: o gestor/gestora se fazer entender por seus colaboradores e os colaboradores serem receptivos no processo de recebimento e 
alinhamento de iniciativas que serão tomadas em conjunto com o gestor/gestora. É fazer com que os funcionários identifiquem o objetivo principal de seus coordenadores, tornando possível a transformação da sua realidade por meio da coletividade.
A Comunicação Organizacional já não se concentra apenas em transmitir informações, mas também em mudar o comportamento dos trabalhadores para que realizem um melhor trabalho, impulsionando a organização em direção às suas metas. (CORRADO, 1994, p.07).

A comunicação deixou de ser um departamento, passou a ser uma prioridade e deve ser efetiva, deixando de ser apenas uma transmissão de informações. Caso contrário, ela pode se voltar contra a gestão uma vez que a interpretação, por sua característica subjetiva, diante de uma orientação/norma/regra é assimilada diferentemente. Desta forma, objetivos não serão alcançados e a consequente desmotivação será inevitável. Quando mal trabalhada, a comunicação pode causar efeitos irreparáveis. A maioria das pessoas lembra com mais facilidade os erros do que os acertos e quando a informação é disparada, não se tem mais o controle sobre ela, pois a sua disseminação é rápida e pode chegar até o público das mais variadas formas possíveis. Por isso, a informação deve ser a mais clara possível para que, mesmo que haja interpretações diversas, a essência da mensagem possa permanecer a mesma, efetivando assim a comunicação desejada.

Freire (1993) desafiou os profissionais da educação ao pensar a construção de projetos educacionais libertadores, que implicassem na postura dialógica como base desse processo libertador. Para o autor, a tarefa é difícil, mas não impossível o que nos permite sonhar com escolas mais abertas e com maior participação de todos, efetivada pelo diálogo crítico em relação a uma existência humana.

Parte complementar da comunicação é a participação, ambos pilares de uma gestão democrática e participativa que se pretende de uma gestão educacional. Mesmo que certos princípios e métodos da organização escolar originem-se da experiência administrativa, seus objetivos se diferenciam, pois, dirigem-se para a educação e para a formação de pessoas, com forte presença das relações interpessoais, resultado de uma ação coletiva de caráter genuinamente pedagógico.

Mesmo a instituição escolar sendo caracterizada por possuir um sistema de relações humanas e sociais com fortes características interativas que a diferenciam das empresas convencionais, a comunicação ocupa um lugar de destaque para que a gestão 
democrática, interativa e participativa, se efetive. Esta visão sociocrítica de gestão corresponde a uma concepção de sistema que agrega pessoas, considerando o caráter intencional de suas ações e interações sociais nas formas democráticas de tomadas de decisões. Disso resulta a organização escolar como construção social da comunidade educacional, cabendo aos gestores saber gerir e conciliar interesses pessoais e coletivos, peculiaridades culturais, preocupar-se com as relações humanas e com os objetivos pedagógicos e sociais, além de estabelecer formas participativas e a eficiência nos processos administrativos. A concepção sociocrítica da educação, norteadora deste artigo, trata das concepções de organização e gestão escolar descritas por Libâneo (LIBÂNEO; OLIVEIRA; TOSCHI, 2012). Diferente da concepção científico-racional ou técnico-científica, a concepção sociocrítica concebe a organização escolar como um sistema que agrega pessoas, destacando-se o caráter intencional de suas ações, a importância das interações sociais no seio do grupo e as relações da escola com o contexto sociocultural e político.

Sobre isso, Paro (2000, p.12) discorre:

Na medida em que se conseguir a participação de todos os setores da escola - educadores, alunos, funcionários e pais - nas decisões sobre seus objetivos e seu funcionamento, haverá melhores condições para pressionar os escalões superiores a dotar a escola de autonomia e de recursos. A esse respeito, vejo no conselho de escola uma potencialidade a ser explorada. [...] E aqui subjaz, portanto, o suposto de que a escola só poderá desempenhar um papel transformador se estiver junto com os interessados, se se organizar para atender aos interesses das camadas às quais essa transformação favorece, ou seja, das camadas trabalhadoras.

Por esse motivo não se deve negligenciar a importância da comunicação na área de gestão, não só a gestão educacional, mas todas e qualquer gestão que se valha da interação com outras pessoas e que objetive a superação de desafios na sua coletividade. A comunicação deve ser utilizada como estratégia para uma boa gestão, portanto, deve haver a preocupação em ser bem aplicada. Pode despertar ideias nas pessoas envolvidas que facilitem o alcance de metas e no planejamento de iniciativas e vai além do processo gerencial, sendo mais abrangente do que projetos, programas e planos, facilitando a harmonização dos desdobramentos das tarefas organizacionais. Sobre esse tema, o autor Pedro Bernardi relata: 
A comunicação é uma ação e um recurso estratégico que se destina a aumentar o rendimento da administração e do planejamento. Ao mesmo tempo, ela pode melhorar o relacionamento entre a hierarquia superior que tem poder de decisão e o pessoal que executa as tarefas, motivar o trabalho em equipe, abrir horizontes para compreensão de objetivos comuns, indicar o direcionamento mais seguro e mais agradável para os passos seguintes e promover sentimentos de bem-estar e qualidade de vida às pessoas. (BERNARDI, 1995, p.40).

Dentro da análise deste tema, Cittadino (1999, p. 231), esclarece que não há, ao que parece, outro caminho para enfrentar as marcantes divisões da sociedade brasileira, buscando superar a cidadania de baixa intensidade, senão conferindo prioridade aos mecanismos participativos que buscam garantir o sistema de direitos fundamentais assegurados pela Constituição Federal.

A comunicação efetiva vai de encontro dos objetivos da gestão participativa ao mesmo tempo em que se observa que, para o processo de tomada de decisões ser realizado coletivamente, é necessário permitir aos membros do grupo discutir e deliberar, em uma relação de colaboração. A organização escolar, a partir da visão sociocrítica aqui relacionada, não é algo objetivo e neutro, mas sim uma construção social de sua comunidade escolar.

\begin{abstract}
Aceitando-se que a gestão democrática deve implicar necessariamente a participação da comunidade, parece faltar ainda uma maior precisão do conceito de participação. A esse respeito, quando uso esse termo, estou preocupado, no limite, com a participação nas decisões. Isto não elimina, obviamente, a participação na execução, mas também não a tem como fim e sim como meio, quando necessário, para a participação propriamente dita, que é a partilha do poder, a participação na tomada de decisões. É importante ter sempre presente este aspecto para que não se tome a participação na execução como fim em si mesmo, quer como sucedâneo da participação das decisões, quer como maneira de escamotear a ausência desta última no processo. (PARO, 2000. p. 16-22).
\end{abstract}

Muitas vezes, o conceito de participação da população em decisões fundamentais para o bom desenvolvimento de atividades dentro do ambiente educacional, é errôneo. É entendido e aplicado de forma errada, pois o gestor tenta convencer os seus colaboradores sobre ações que estavam pensadas, elaboradas e estipuladas por ele mesmo, ou seja, o gestor não cria um ambiente de cooperação entre os professores, mas sim de aceitação daquilo que de alguma maneira já estava estabelecido. 
A comunicação determina atitudes e promove a criação de representações sociais, tanto com relação a aspectos políticos, econômicos, sociais como educacionais. O gestor, muitas vezes é influenciado por representações sociais impostas por determinados segmentos da sociedade, ou seja, a representação social assumida por um gestor pode ser também a forma pela qual ele foi educado, como por exemplo, os valores, princípios, a cultura e os costumes que lhe foram apresentados. Todos estes fatores influenciam de alguma forma a maneira pela qual o indivíduo exerce suas ações ou toma suas decisões.

Coerente com essa preocupação, Moscovici distingue inicialmente o conceito de representação social dos mitos, da ciência e da ideologia. Em seguida, coteja-o com conceitos de natureza psicológica que lhe são freqüentemente associados, como os de opinião, atitude e imagem. Basicamente, afirma que esses conceitos (tal como eram tipicamente tratados à época) pressupunham a existência de um estímulo externo, dado ao qual o indivíduo responde. (ALVES-MAZOTTI, 2008, p.22).

O gestor pode apresentar em seu ambiente de atuação duas atitudes de conceitos diferentes e que determinam a representação social pela qual obteve maior influência, os conceitos de objetivação e de ancoragem. A primeira refere-se aos princípios e valores que a pessoa já possui e aplica, e a segunda é aquela na qual a pessoa também se ancora em conceitos pré-estabelecidos por representações e movimentos sociais, além da bagagem cultural que já possui. Em uma pesquisa que será aplicada, por exemplo, a forma como a análise é feita deve ser diferenciada por grupos e dependendo da pesquisa aplicada, uma parte/vontade/iniciativa da pessoa se sobressairá mais que a outra. A comunicação é bastante importante neste processo, pois tanto pode idealizar e passar informações manipuladas e errôneas no processo de atuação deste gestor educacional, como também pode auxiliar em trabalhos e relações humanas.

Na difusão, relacionada à opinião, não há diferenciação entre fonte e emissor, na medida em que, por exemplo, aqueles que transmitem as informações através dos meios de comunicação, por sua vez, as receberam dos especialistas. Os temas são pouco ordenados entre si e os diferentes pontos de vista apresentados podem ser contraditórios. Já a propagação, relacionada à atitude, é feita por um grupo que produz uma visão de mundo bem organizada, que dispõe de uma crença a ser disseminada e a ser acomodada aos saberes estabelecidos. Finalmente, a propaganda, ligada aos estereótipos, é uma forma de comunicação que se inscreve em relações sociais, no conflito entre o saber "verdadeiro" e o "falso", visando a recusa da concepção rival através da apresentação 
consistente e rígida de uma visão competidora. (ALVES-MAZOTTI, 2008, p.36).

Outro desafio bastante importante que os gestores educacionais enfrentam, além de terem que utilizar de forma adequada a comunicação efetiva, de deliberar funções, de trabalhar com representações sociais que ele mesmo possui e que cada um de seus colaboradores também apresentam, o gestor precisa saber trabalhar com regras, normas, legislações e burocracias diariamente. E estas regras e normas influenciam a forma pela qual os professores reagem a determinadas atitudes que o gestor muitas vezes é obrigado a tomar.

À medida que o potencial embutido na ação comunicativa é realizado, o núcleo normativo arcaico se dissolve e abre caminho para a racionalização das visões de mundo, para a universalização da lei e da moralidade e para uma aceleração dos processos de individuação (HABERMAS, 1987a, p. 4b).

Estas visões de mundo, familiares, sociais, educacionais, políticas, econômicas, normativas, dentre outras, fazem com que o gestor determine a maneira pela qual irá tomar atitudes e ações nas mais variadas situações. Determinará também, se irá utilizar da comunicação efetiva para auxiliar na solução de problemas e na implantação de alguma medida ou iniciativa.

Desde as primeiras pesquisas sobre os grupos de referência constatou-se que nem sempre existe uma relação de causalidade simples entre a pertença do indivíduo a um grupo e o grau em que ele partilha as opiniões de seus outros membros. Cada indivíduo tem vários grupos de pertença: alguns deles servirão mais de pontos de ancoragem de suas opiniões e crenças do que outros. Grupos aos quais um indivíduo não pertence, mas a que aspira pertencer, podem também desempenhar um papel de ancoragem. (DOISE, 2001, p.187).

O fato de um gestor possuir uma forma de pensar e de agir diferenciada da maioria dos outros gestores é outro aspecto que pode contribuir beneficamente ou não na introdução de uma gestão democrático-participativa com a utilização da comunicação efetiva.

Mesmo o gestor tendo a visão de que se os seus colaboradores participarem mais ativamente das decisões que regem uma instituição escolar, mesmo o gestor sabendo que se promover ações que contribuam ainda para a inserção dos alunos, pais e comunidade é extremamente positivo para o seu trabalho e a instituição como um todo. 
A pessoa, ou seja, neste caso em específico o gestor, precisa da ancoragem em algo que lhe ofereça aceitação por parte do grupo que pertence e demais segmentos que o rodeia.

Em algumas situações da gestão, a cultura existente e enraizada na pessoa que possui este cargo acaba imperando. Impera, porque ela busca a bagagem que já adquiriu, as experiências pelas quais já passou e qual foi a reação diante destas experiências. Todas estas características determinam a forma pela qual o gestor irá trabalhar as suas atitudes e ações cotidianas. E é neste momento que pode ser identificado se o gestor realmente utilizou a comunicação efetiva como ferramenta e complemento da gestão democrático-participativa.

\section{Considerações finais}

Após análise e leitura dos textos e autores apresentados neste artigo, foi possível verificar a estreita relação entre a gestão educacional e a comunicação efetiva.

A relação entre ambas se torna evidente quando são observadas as consequências dela nas práticas da organização educacional, por meio do entendimento do papel dos sujeitos da comunicação. Processos comunicativos põem em cena indivíduos como sujeitos $d a$ e em comunicação.

Segundo os autores supracitados, o que se pode observar nas diversas teorias existentes sobre comunicação é que estas abordagens destacam o papel centralizador do emissor no processo comunicativo. Diferente do receptor, que, ao receber o estímulo, reage diferentemente do restante do grupo, considerado então como um indivíduo dotado de estruturas psicológicas complexas e que, portanto, acolhe e reage diferentemente aos estímulos recebidos.

Nas instituições de ensino privadas a indicação para o cargo de gestor ou gestora, geralmente é feita pela entidade mantenedora. Escolhem um dos professores do corpo docente ou realizam um processo seletivo com profissionais do mercado.

Independente da forma como o professor chega a ocupar o cargo de gestor, precisa ter consciência que a comunicação é primordial para uma gestão democráticoparticipativa.

Há de se considerar inúmeras variáveis que interferem na comunicação de qualquer instituição de ensino, seja ela pública ou privada, com ou sem fins lucrativos, independente do processo de sucessão que ela adota, pois ainda que uma instituição de 
ensino adote a eleição entre seus pares para a mudança de gestor, ao assumir o cargo ele pode se tornar extremamente autoritário e não adotar uma comunicação efetiva.

Os gestores/gestoras educacionais devem levar em consideração as características da comunicação efetiva para que, com elas, possam se valer e verificar o andamento do próprio trabalho. Ouvir e não só se fazer ouvir. Permitir a participação e lutar para que ela aconteça como forma de garantia do Estado Democrático de Direito. Realizar ações que priorizem a concretização dos ideais sociocríticos e que permitam a aplicabilidade da gestão democrático-participativa como forma de estabelecer uma sociedade que seja justa, econômica e social, a todos. Perceber o espaço educacional como espaço de relações que devem ser enriquecidas com a troca de experiências, ideias e conhecimento, em respeito à diversidade e individualidades, em respeito ao ser humano que ali se encontra em formação, caracterizando, na realidade, a comunidade escolar como um todo.

Cabe ainda ressaltar que, o canal de comunicação escolhido pelo gestor ou gestora também é fundamental para concretizar a gestão democrático-participativa.

A utilização de ambientes virtuais, internet, e.mails, whatsapp, entre outros, tem contribuído sem nenhuma dúvida, para a veiculação da informação, pois reduz o tempo, a distância entre as pessoas, no entanto, nem sempre os avanços tecnológicos produzem os resultados desejados para uma comunicação efetiva, pois compartilhar ideias, problemas, buscar soluções, resolver conflitos exige presença.

A percepção das reações das pessoas diante das situações que se apresentam no cotidiano escolar é um aspecto que deve ser considerado, tendo em vista que conforme a reação faz-se necessário modificar, adequar o diálogo, repensar as palavras, rever as posições, o que não pode ser feito por meio de, por exemplo, e.mails.

As decisões podem ser socializadas por diversos canais quando já foram discutidas; quando os problemas já foram resolvidos de forma coletiva e há necessidade de registrar o resultado das reuniões, dos diálogos, ou para colher a opinião geral antes de resolver uma situação.

Ter em mente as possibilidades da comunicação e sua efetividade, para que possa ser aplicada no cotidiano educacional, visando à qualidade da educação ofertada por meio da participação dentro do ambiente educacional, faz com que os papéis dos sujeitos envolvidos fiquem claros, facilitando o seu próprio reconhecimento assim como a sua responsabilização, desde os rumos que devam ser tomados, para a melhoria contínua do processo educacional. 


\section{Referências}

ALVES-MAZZOTTI, A.J. Representações sociais: aspectos teóricos e aplicações à Educação. Revista Múltiplas Leituras. v.1, n. 1, p. 18-43, jan. / jun. 2008. Disponível em: <https://www.metodista.br/revistas/revistasims/index.php/ML/article/view/1169/1181> . Acesso em: 25 abr. 2016.

BERNARDI, P. A. A Comunicação na Gestão de Instituições de Ensino Superior. Curitiba: Champagnat, 1995.

CADEMARTORI, D. M. L.; MENEZES NETO, E. J. Poder, meios de comunicação de massas e esfera pública na democracia constitucional. Sequência, Florianópolis, n. 66, p. 187-212, Julho. 2013. Disponível em: $<$ http://www.scielo.br/scielo.php?script=sci_arttext\&pid=S217770552013000100008\&1 ng=en\&nrm=iso>. Acesso em: 25 abr. 2016.

CITTADINO, G. P. Direito e Justiça Distributiva. Rio de Janeiro: Lúmen Júris, 1999.

CORRADO, F. M. A Força da Comunicação. São Paulo: Editora Makron Books do Brasil, 1994.

COLOMBO, S. S. et al. Gestão Educacional: uma nova visão. Porto Alegre: Artmed, 2004.

DEMO, P. Participação é conquista: noções de política social. São Paulo: Cortez, 2009.

DOISE, W. Atitudes e representações sociais. Rio de Janeiro: Editora da Universidade do Estado do Rio de Janeiro, 2001.

FRANÇA, V. Sujeitos da comunicação, sujeitos em comunicação. In: Na mídia, na rua: narrativas do cotidiano. Belo Horizonte: Autêntica, 2006, p.61-88.

FREIRE, P. Pedagogia do oprimido. São Paulo: Cortez, 1993.

HABERMAS, J. (1987b). A nova instransparência. A crise do Estado de bem-estar social e o esgotamento das energias utópicas. Novos Estudos Cebrap. São Paulo, 18: 103-114, setembro.

HOHLFELDT, A.; MARTINO, L.; FRANÇA, V. Teorias da Comunicação: conceitos, escolas e tendências. Editora: Vozes, 2013.

LIBÂNEO, J. C. Concepções e Práticas de Organização e Gestão da Escola: Considerações Introdutórias para um Exame Crítico da Discussão Atual no Brasil. Revista Española de Educación Comparada, Madrid, n. 13, 2007. Edición monográfica: Administración y gestión de los centros escolares: panorámica internacional. 
LIBÂNEO, J. C.; OLIVEIRA, J. F.; TOSCHI, M. S. Educação escolar: políticas, estrutura e organização. São Paulo: Cortez, 2012.

MACHADO, L. M.; FERREIRA, N. S. C. (orgs.). Política e Gestão da Educação: Dois Olhares. Rio de Janeiro: DP\&A, 2002.

PARO, V. H. Gestão democrática da escola pública. 3.ed. São Paulo: Ática, 2000.

ROCHA, I. N. Gestão Estratégica de Conhecimento e Competências: administrando incertezas e inovações. Brasília: Universa, 2003.

\section{Como referenciar este artigo}

BARAZETTI, Vanessa Rita et al. A estreita relação entre a comunicação efetiva e a gestão democrático-participativa. Revista on line de Política e Gestão Educacional, Araraquara, v.20, n.2, p. 166-184, 2016. Disponível em: <http://dx.doi.org/10.22633/rpge.v20.n2.9456>. ISSN: 1519-9029.

Submetido em: maio/2016

Aprovado em: nov/2016 